\title{
Perceived Corporate Glass Ceiling: A Survey Research in Bangladesh Corporate Job Sectors
}

\author{
Chhanda Karmaker ${ }^{1 *}$, Kaniz Fatema ${ }^{2}$ \\ ${ }^{1}$ Assistant Professor, Department of Psychology, University of Dhaka, Dhaka, BANGLADESH \\ ${ }^{2}$ Former Student, Department of Psychology, University of Dhaka, Dhaka, BANGLADESH \\ *E-mail for correspondence: chhanda.karmaker@gmail.com
}

https://doi.org/10.18034/abr.v10i3.483

\begin{abstract}
The study investigated the perceived corporate glass ceiling and measured the leading factors of the glass ceiling according to gender, company types, and years of work experience. 257 adult male and female employees participated in this study as respondents, and they were from four districts of Bangladesh working in banks, multinational companies, private firms, and telecommunication sectors following a convenient sampling technique. The results revealed that $60.7 \%$ of the respondents perceived a glass ceiling exists in the workplace of Bangladesh. The researchers used mean of means analysis to compare the perceptual differences regarding the leading factors of glass ceiling according to gender, company types, and working experience and found work-life conflict as the most important factor for causing the glass ceiling.
\end{abstract}

Key words: glass ceiling, women, stereotypical view, discriminatory practice

\section{INTRODUCTION}

The glass ceiling is an unrecognized circumstance or obstacle, usually regarding women or minority groups that prevent their progress to a certain level in a hierarchy at the workplace. According to Afza and Newaz (2008), the glass ceiling is the invisible barrier of obstructions that exists in the organizations and block female employees from achieving elevated career success. In other words, it is a situation where qualified people unable to advance their career position due to some forms of discrimination, mostly sexism or racism (Nazmul et al., 2016). The glass ceiling is one of the utmost influential metaphors for assessing the disparities between male and female workers within the work environment (Islam and Jantan, 2017). Carol Hymowitz and Timothy Schellhardt first introduced the concept of "glass ceiling" in an article named "Wall Street Journal" in 1986, where they defined it as the hidden barriers that hinder women's career growth in the American workforce (Eleanor, 2014). However, the term glass ceiling was claimed by Lawrence and Schreiber before 1984 who described that the organizational policy seemed transparent and systematic, but unfortunately, this was not so transpicuous rather, in reality, women faced a lot of unacknowledged obstacles that limit their career progress (Baker and Lightle, 2001).
Bangladesh is a developing nation, and here, the society is mainly male centered or patriarchal society. Hence, women are dominated in different levels of their lives by the men and have to fight to get their proper rights in every sector like family, society, and the whole state (Farhana and Stephen, 2019). Men are playing the role of authority who can exert their power and take every decision as they are far better and efficient than women. On the other hand, society perceived women as dependent, submissive, timid, unassertive, frail, and acquiescent. This type of pre-occupied thought makes women different from men from their births. In the case of getting a job, men are always the first choice by the employers as they are considered more efficient and strategic as well as having high achievement motivation and decision-making capabilities. Whereas, they recruit women only for some so-called feminine occupations like a school teacher, nurse, secretary rather than for administrative and managerial jobs. This type of discrepancy is quite natural in different job segments of the developing countries. (Nazmul et al., 2016). Research evidence suggests that women executives are not only deprived of getting the opportunity to reach their career ladder but also experience wage inequalities despite their qualifications and suitability (Ahmad and Naseer, 2015). 
The explanation of the male-dominated corporate culture behind this gender disparity is that women are less skilled and proficient as well as not highly motivated towards their job's responsibilities, and they are easily affected by an illness, which causes frequent absenteeism. Moreover, marriages, pregnancies, and child-rearing interrupt their job duties. Research also suggests that women's career progress mainly depends on organizational policy and management perception rather than their education and qualification (Liff and Ward, 2001).

However, our society is changing gradually, and the participation rate of women in higher education and different job sectors has increased immensely over the past few decades. Due to the rapid growth of ready-made garment industries in Bangladesh, the demand for female workers has sharpened tremendously. But surprisingly, the existence of female executives in the senior or leadership position in this sector or other job sectors is quite rare, which signifies that highly educated and qualified middle and upper-class females still face numerous barriers in the job market and also experience difficulty getting promoted in the organization hierarchy despite having required qualifications (Khan, 2001). Gender discrimination and inequity create such a barrier in the workplace that forces them to stop at a specific level of the position. Not necessarily, these barriers are visible to identify but rather exist, which is known as the metaphor "glass ceiling."

Afza and Newaz (2008) studied the determining factors for the presence of a glass ceiling in Bangladesh and found five aspects regarding the glass ceiling. They are management perception, work environment, work-life conflict, sexual harassment, and organizational policy. The respondents emphasized most on management perception and work environment, whereas they gave less emphasis on sexual harassment.

Habib (2015) also examined the glass ceiling existence in the corporate telecommunication sector in Bangladesh. The study result showed significantly lower career progression of women compared to the man in the telecommunication industry. The researcher found a similarity with the article of the Wall Street Journal publication of 1986. Even the participants of the study pointed out the unrealistic requests from management level impacted their work-life balance.

Islam and Jantan (2017) found the presence of the glass ceiling in Bangladesh ready-made garment industries. Islam et al. (2018) also examined the key contributors that prevent the professional progress of female employees and identified three main barriers- organizational culture, social culture, and lack of career encouragers.

\section{Significance of the Study}

The existence of the glass ceiling is a common scenario according to different previous studies and researches.
But those studies collected data only from women and excluded the viewpoint and perception of another gender. All the previous studies also ignored some other issues like the work experience in the current workplace, different types of job sectors, which could be crucial factors in determining the glass ceiling effect and its existence. Thus, the present study aimed to focus the perceived corporate glass ceiling existence and the leading factors that differentiate women from their male colleagues when it comes to getting a high-level decisionmaking job as well as take a leadership position.

\section{METHOD}

\section{Participants}

This study took two hundred forty-seven employees $($ men $=131$, women $=126)$ as participants by using a convenient sampling technique. They were working in four selected corporate job sectors- banking sector, telecommunication sector, multinational companies, and private firms and having work experience more than two months to ten years. Their ages were ranged from 23 years to 55 years. And they were from four districts of Bangladesh (Dhaka, Sylhet, Jashore, and Chattagram).

\section{Measures}

\section{Demographic and Personal Information Form}

A demographic and personal information form was used to know about the respondent's age, gender, educational status, company type, and working experience. A closeended question regarding the existence of a glass ceiling for women at their workplace was attached at the end of this form.

\section{Bangla Translated Version of Glass Ceiling Questionnaire}

Afza and Newaz (2008) developed the original scale, named "The Questionnaire on the Factors of Glass Ceiling." It is a close-ended questionnaire having 14 items under five factors regarding the glass ceiling. All the statements of this scale were seven-point Likert-type ranging from strongly disagree to strongly agree. Through factor analysis, five factors of the glass ceiling were determined. These are (1) management perception, (2) work environment, (3) worklife conflict, (4) sexual harassment, and (5) organizational policy. The Kaiser-Meyer-Okin (KMO) Measures of Sampling Adequacy showed a high value (.580>.5), which indicated the appropriateness of the factor analysis. The principal component analysis showed that those five factors could explain $73.909 \%$ of the cumulative variation.

\section{Procedure}

The researchers of the present study translated the original scale into Bangla language. Then it was given for correction to three respectable teachers of Dhaka University, who were fluent in both English and Bangla, and also knowledgeable about the steps of scale 
translation. Researchers checked the correction forms and made necessary modifications based on the feedbacks of the correction forms. It was then revised by one research expert about the efficiency and structure of the patterns of the scales for the survey. Then the final questionnaires were prepared both in printed form and Google form.

Data were collected only from the people who were willing to participate in the study, and it took around four months to accomplish the data collection process. After giving proper instruction, the researchers asked the respondents to fill up the demographic and personal information blank. At the end of the form, there was a close-ended question: "Do you think that gender discrimination exists in the workplace in the context of Bangladesh?" The respondents were requested to reply within three response options-yes, no, or neutral. Then respondents were asked to fill up all the items of the next questionnaire. The researchers assured them about the confidentiality of their information and gave thanks for their participation.

\section{RESULT}

The current study used frequency distribution along with percentage and comparing means to measure the perceived glass ceiling existence and the perceptual differences of its leading factors according to gender, company types, and working experience.

Table 1: Percentage of Perceived Glass Ceiling Existence

\begin{tabular}{|c|c|c|}
\hline Exist/not & Frequency & Percent \\
\hline Yes & 156 & $60.7 \%$ \\
No & 59 & $23 \%$ \\
Neutral & 42 & $16.3 \%$ \\
\hline
\end{tabular}

Table 1 showed that $60.7 \%$ of the respondents agreed about the existence of the discrimination practice against women in the workplace, only $23 \%$ denied, and $16.3 \%$ of respondents took a safe place by expressing a neutral position in this regard. That outcome would be able to direct that people perceived the glass ceiling existed in the workplace of Bangladesh, which is a matter of thought.

Table 2: Comparison of mean of means of the glass ceiling factors between male and female respondents.

\begin{tabular}{|c|c|c|c|c|c|}
\hline Gender & $\begin{array}{c}\text { Management } \\
\text { perception }\end{array}$ & $\begin{array}{c}\text { Work } \\
\text { environment }\end{array}$ & $\begin{array}{c}\text { Work-life } \\
\text { conflict }\end{array}$ & $\begin{array}{c}\text { Sexual } \\
\text { harassment }\end{array}$ & $\begin{array}{c}\text { Organizational } \\
\text { policy }\end{array}$ \\
\hline Female $(n=126)$ & 3.05 & 3.03 & 4.00 & 2.82 & 1.80 \\
\hline Male $(n=131)$ & 2.76 & 3.12 & 4.06 & 2.64 & 1.45 \\
\hline
\end{tabular}

Table 3: Comparison of mean of means of the glass ceiling factors among different company types

\begin{tabular}{|c|c|c|c|c|c|}
\hline \multicolumn{7}{|c|}{ Factors of the glass ceiling } \\
\hline $\begin{array}{c}\text { Company } \\
\text { type }\end{array}$ & $\begin{array}{c}\text { Management } \\
\text { perception }\end{array}$ & $\begin{array}{c}\text { Work } \\
\text { environment }\end{array}$ & $\begin{array}{c}\text { Work-life } \\
\text { conflict }\end{array}$ & $\begin{array}{c}\text { Sexual } \\
\text { harassment }\end{array}$ & $\begin{array}{c}\text { Organizational } \\
\text { policy }\end{array}$ \\
\hline $\begin{array}{c}\text { Bank } \\
(n=39)\end{array}$ & 3.01 & 2.31 & 3.42 & 1.56 & 3.06 \\
\hline $\begin{array}{c}\text { Multinational } \\
(n=118)\end{array}$ & 2.97 & 2.37 & 3.30 & 1.74 & 3.04 \\
\hline $\begin{array}{c}\text { Private firms } \\
(n=30)\end{array}$ & 2.79 & 2.18 & 3.33 & 1.27 & 3.24 \\
\hline $\begin{array}{c}\text { Telecommunication } \\
(n=70)\end{array}$ & 2.77 & 2.41 & 3.15 & 1.60 & 3.08 \\
\hline
\end{tabular}

Table 4: Comparison of mean of means of the glass ceiling factors according to the respondents' experience levels

\begin{tabular}{|c|c|c|c|c|c|}
\hline \multicolumn{7}{|c|}{ Factors of the glass ceiling } \\
\hline $\begin{array}{c}\text { Experience } \\
\text { level }\end{array}$ & $\begin{array}{c}\text { Management } \\
\text { perception }\end{array}$ & $\begin{array}{c}\text { Work } \\
\text { environment }\end{array}$ & $\begin{array}{c}\text { Work-life } \\
\text { conflict }\end{array}$ & $\begin{array}{c}\text { Sexual } \\
\text { harassment }\end{array}$ & $\begin{array}{c}\text { Organizational } \\
\text { policy }\end{array}$ \\
\hline $\begin{array}{c}0-1 \text { year } \\
(n=102)\end{array}$ & 3.10 & 3.07 & 3.75 & 2.67 & 1.47 \\
\hline $\begin{array}{c}1-3 \text { years } \\
(n=94)\end{array}$ & 2.87 & 3.15 & 4.35 & 2.74 & 1.62 \\
\hline $\begin{array}{c}3-6 \text { years } \\
(n=35)\end{array}$ & 2.82 & 3.06 & 4.16 & 2.76 & 1.94 \\
\hline $\begin{array}{c}6 \text { years-more } \\
(n=26)\end{array}$ & 2.38 & 2.84 & 3.83 & 2.87 & 1.81 \\
\hline
\end{tabular}


Table 2 showed gender differences in the perception of the principal factors of the glass ceiling. Both men and women perceived 'work-life conflict' as the most significant factor of the glass ceiling. That means, according to both gender, balancing between personal life and scheduled working hour, and duties seemed to be difficult for women.

Table 3 also expressed 'work-life conflict' as the most leading factor followed by organization policy, management perception, working environment, and sexual harassment.

Table 4 showed that the first leading factor perceived by every level was the 'work-life conflict.' But the respondents who had 0 to 1 year of working experience perceived 'management perception' as the second leading factor, whereas 'work environment' considered as the second leading factor by those who had more than one year of experience.

\section{Discussion}

The current study has highlighted the perception of gender regarding the presence of the glass ceiling as well as its contributing factors in Bangladesh's corporate job sectors. The findings revealed that $60.7 \%$ of respondents (both male and female) perceived the existence of the glass ceiling in the workplace, and only $23 \%$ denied its presence whereas $16.3 \%$ took a neutral position on this issue. The reason for standing in such a safe opinion may be the feelings of hesitation or anxiety to express their views. However, most of the respondents granted that women are facing professional prejudiced practices in their career progression. This result also supports earlier research findings, where the existence of a glass ceiling was found among the women employees in the private organizations in Dhaka city (Afza and Newaz, 2008; Habib, 2015).

Our male-dominated society has changed a lot, and Bangladesh has become a role model in the women's empowerment sector in the past decades. The Gender Gap Index of 2017 showed how this country continues the progression in women's empowerment to secure the first position in gender equality among the South Asian countries. The number of working women steadily upgraded from 16.2 million in 2010 to 18.6 million in 20162017. So, the statistics show a positive sign of a good ratio of new women's entry in various job sectors, which indicates that they are trying to break the glass ceiling practice. But our current study results showed the reality that the discriminatory practices against female employees are still present in different job factors in Bangladesh. Now the question is which factors are responsible for creating this biased thought and practice. The researchers also explored this area and found worklife conflict played the most significant role in this glass ceiling. By comparing the mean of means between two genders, the results revealed that both perceived work-life conflict as the most leading factor of the glass ceiling.
However, a difference was observed in the case of the second-leading factor; women believed management perception, whereas men thought that the work environment was the next contributing factor for this inequality. Compared to the study of Afza and Newaz (2008), these findings showed some changes from the year 2008 as the research's respondents (only females) agreed management perception and work environment were the main essential aspects for generating a glass ceiling in the workplace, whereas, organizational policy and work-life conflict played the second important role for it.

In the case of the perceptual differences of the glass ceiling factors among different company types and working experience, the results revealed no variation as all perceived work-life conflict as the key factor that causes the glass ceiling.

Balancing both job and family responsibilities is very difficult for working women, and it is one of the main barriers for them to attain a leading position in their workplace. And sometimes they have to decide by choosing any one of them. If they select a career-oriented life where they have a chance to achieve a top position, they may have to compromise the motherhood and family life. On the other hand, accepting an ordinary job allows them to balance their work-life as well as their family life, but it prevents them from reaching the career ladder. And today's common scenario is that many highly educated and qualified women employees give up the opportunities or switch their careers just to reduce worklife conflict. So, it is high and right time to consider this alarming factor for breaking down sex segregation in occupation. Organizations should take this issue seriously and implement new policy frameworks to tax the gender inequality in the workplace. They should also change this stereotypical attitude and give women employees flexibility in work, especially in working hours and an open-minded approach for ensuring the right balance. Also, it is essential to create awareness among families and communities to minimize the glass ceiling effect. Their support and cooperation will act as a buffer to the working women as well as help them to reduce their burdens.

\section{Limitations of the Study}

Though the researchers have tried best to meet the research objective, there are some limitations to the research. For time and financial constraints, it was not possible to take a large sample from more than four districts of Bangladesh. The researchers could not collect all the data by meeting the respondents directly, so many momentous feedbacks from the respondents remained unreachable.

\section{Further Research Direction}

Further studies can be carried out, including more types of private companies and also public sectors. There is also 
a scope to add to this research to run qualitative research with a sample of unemployed graduated women to investigate the reasons behind their unemployment, whether it is their willingness not to work outside, or it is because of malpractice of hiring policy, or any other intention.

\section{CONCLUSION AND IMPLICATIONS}

Based on the results of this present study, we conclude that the glass ceiling exists in Bangladesh's corporate job sectors that often block female employees' professional advancement. In other words, we can say that a large number of qualified and skilled women fail to secure a senior and authoritative position because of this invisible barrier. Bangladesh is a middle-income country, and nearly half the populace is women. If they get a chance like men to work with the best position and highestgrossing jobs, the nation can become more developed and affluent. So, organizations need to take some necessary initiatives to break this inequity. First of all, management should change the stereotypical viewpoint against woman employee as well as have the will to reduce the glass ceiling effect. Secondly, they can use a blind screening process in the case of recruiting and promoting candidates as it is the best way to select the employees based on their qualifications. Finally and most importantly, family members should give them some space to prepare themselves as the potential for their jobs as well as to develop a strong desire to achieve their career goal.

\section{REFERENCES}

Afza, S.R., \& Newaz, M.K. (2008). Factors Determining the Presence of Glass Ceiling and Influencing Women Career Advancement in Bangladesh. BRAC University Journal, 5(1), 85- 92.

Ahmad, M. \& Naseer, H. (2015). Gender Bias at the Workplace: Through Sticky Floor and Glass Ceiling: A Comparative Study of Private and Public Organizations of Islamabad. International Journal of Management and Business Research, 5(3), 249-260.

Baker, B \& Lightle, S. S. (2001). Cracks in the Glass Ceiling: An Analysis of Gender Equity in the Federal Government Auditing Career Field. The Journal of Government Financial Management, 50(3), 18-26.

Eleanor, W. (2014). Diversity Culture and the Glass Ceiling. Journal of Cultural Diversity, 21(3), 83-9.

Farhana, H. \& Stephen, C. D. (2019). The Energy of Corpuscular Wave Mechanism. Int J Conf Proc. 1(2). ICP. 000509.2019.

Habib, L. (2015). A Study on the Existence of the Glass Ceiling in the Telecommunication Sector of Bangladesh. IOSR Journal of Business and Management, 17(12), 34-38.

Islam, M., Jantan, A., Hashim, H., Chong, C., \& Abdullah, M. (2018). Factors Influencing Female Progression in Leadership Positions in the Ready-Made Garment (RMG) Industry in Bangladesh. 1. 1-13.

Islam, M. \& Jantan, A. (2017). The Glass Ceiling: Career Barriers for Female Employees in the Ready-Made Garments (RMG) Industry of Bangladesh. Academy of Strategic Management Journal. 16. 1939-6104. 10.2139/ssrn.3414583.

Khan, S. R. (2001). The Socio-Legal Status of Bengali Women in Bangladesh: Implications for Development. Dhaka University Press.

Liff, S. \& Ward, K. (2001). Distorted Views through the Glass Ceiling: The construction of Women's Understandings of Promotion and Senior Management Positions. Gender, Work \& Organizations. 8(1), 19-36.

Nazmul, A. K., Islam, N., \& Alam, M. M. (2016). Glass Ceiling Factors, Job Satisfaction, and Job Switching Decisions of Female Employees in Private Sector Enterprises of Bangladesh. The Business Review. 5, 79-97. ISSN: 1996-3637.

The Gender Gap Index (2017). World Economic Forum. Retrieved from: http://www,weforum.org/reports/theglobal-gender-gap-report-2017.

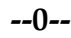




\section{How to cite this article}

Karmaker, C., \& Fatema, K. (2020). Perceived Corporate Glass Ceiling: A Survey Research in Bangladesh Corporate Job Sectors. Asian Business Review, 10(3), 153-158. https://doi.org/10.18034/abr.v10i3.483 